\title{
Putting Community into Community Event: Volunteer Management in Madhyapur Thimi Bisket Jatra
}

\author{
Ramesh Rasik Paudel \\ Faculty, Nepal Commerce Campus, TU \\ ramesh.rasik@gmail.com
}

\begin{abstract}
This paper aims at giving a description and an assessment of the volunteer management in the Bisket Jatra, the cultural event of Madhyapur Thimi. The recruitment, selection, supporting, training and retention processes of the volunteer have been studied in order to find how the policies of the volunteer management differ in the community-based cultural event to the modern models used in organizational world. The bases of the recruitment, selection, task divisions in the Bisket Jatra are the casts, sub-casts within the Newar community and the quarters of Thimi they belong to. This paper tries to assess how effective such community-based volunteer program can be and how successfully they help deliver the event, with the increased sense of belonging and the cultural pride among the volunteers. For this, qualitative ethnographic research has been made using snowball sampling technique. The data collected through the interviews has been analyzed using descriptive method in order to show how the whole community takes charge of different tasks and coordinates as a team in the Bisket Jatra.
\end{abstract}

Keywords: Bisket Jatra, Event Management, Cultural Event, Volunteer Management.

\section{Introduction}

The whole range of events from the mega events to small local events is "heavily dependent on volunteers for their operations" (Smith et al., 2014, p.1). Volunteers play a key role in all cultural events. The commitment of volunteers in preparing and staging the events play vital role in creating event experience for participants. This study focuses on such role of the volunteers in Bisket Jatra, a regional cultural event of Bhaktapur District. It aims at exploring volunteer management in the event and how the ethnicity and locality 
become the basis of such processes as recruiting, tasks dividing and coordinating the locals. It attempts to interrogate how the cultural norms help recruiting the right people at the right place, develop the sense of belonging in the volunteers and retention of the volunteers.

Bisket Jatra is one of the vivid cultural events in Nepal and it is celebrated in antiquated city of Bhaktapur. The term Bisket Jatra is derived from Newari word "Bi" and "Syaku" and it means "the festival after the death of pythons" (Sayami, 1972, p.45). There are various stories about the origin of the festival. Sayami (1972) states, "In Bhaktapur fabulous and mythical but interesting stories are narrated for the origin of the Bisket festival" (p.46). There are variations not only in the origin of the festival but also in the way the specific areas of Bhaktapur District celebrate the Jatra. Sthrestha (2013) notes, "While Bisket is observed for nine days in Bhaktapur, it lasts only three days in Thimi where it is popularly known as Sindoor Jatra or Dyo Jatra" (para. 2). Bisket in Thimi is the festival of chariots, music, colours and crowd. Shrestha (2013) affirms, "Distinguished by pageant marriage between vermillion and Dhimey- the most popular among Newari drums, Bisket often compels local spectators to leave the comfort of their balcony and join the youthful jubilation sweeping down the streets" (para. 1). The people participate in parade carrying the chariots of gods and spraying vermillion powder to each other. The procession is accompanied by the beating of Dhimey. People visit each other's areas and worship all the chariots' gods.

On the first day of the year of the Bikram Era, Bisket Jatra takes place in evening in Siddhikali of Thimi. On the second day, 32 chariot-festival takes place at Balkumari and the temple is rotated by the participants. While playing with vermillion, they draw chariots, the lights and play Dhimey. Binay Prajapati (2017) explains:

On Baisakh $1^{\text {st }}$ of every year (second day of Jatra), Jatra takes place at evening in Siddhikali Temple. This Jatra is known as Bya-li-siya Jatra. On the Baisakh $2^{\text {nd }}$ (last day of Jatra),Jatra takes place at Balkumari Temple at early morning. This Jatra is known as Sutha-Siya Jatra. The khaths (palanquins) are gathered around Balkumari and are revolved around the temple by the participants playing with sindur, singing and dancing in the tune of Dhimey Baja. (para. 5) Bisket Jatra witnesses many participants along with thousands of visitors and it involves parades with chariots of deities, worshipping them and much merrymaking. Bisket Jatra is comprised of various activities and several Jatras commemorated at different quarters of Madhyapur Thimi. The operation and staging of the multi-dimensional event like Bisket are impossible without the rigorous involvement of the local volunteers.

The study focuses on the volunteer management in different aspects of the event of Bisket Jatra of Madhyapur Thimi. It aims at finding the ethnic and sub-castes constituencies in different arena of Bisket Jatra, the event completely reliant on the volunteers. It seeks the answer to the questions: how diverse castes and sub-castes of Newar ethnicity help the community- based volunteer management in the Bisket Jatra? 
What is the spectrum of volunteer roles in the event? How does affiliatory motivation works in case of community-based volunteer management?

Managing a cultural event is a demanding undertaking. Cultural event management team needs skills in fundraising and finance, public relations and preserving local sensitivities. Typically, event management team has to manage tight budgets, volunteers, visitors, spectacles, safety and so on. Bisket Jatra is also such cultural event that is linked to the identity and faith of the community. But this study limits itself to the role and management of volunteers, but not the other aspects of the event management.

\section{Literature Review}

An event is an activity that gathers the people in a particular setting, where a message is communicated and experience is created. The term event is used to refer to different activities designed for different purposes. These activities can be art, sports, tourism, business, entertainment and social activities. The events can be public or private, commercial or charitable, celebratory or commemorative. Getz (2008) defines events as, "a spatial-temporal phenomenon, and each is unique because of interactions among the setting, people, and management systems-including design elements and the program" (p. 404). Getz elucidates that each event is created for a purpose, all events are different, and the attendees get the unique experience out of the event. The celebration and experience are two significant aspects of the events.

Events can be classified on the basis of scale, place and purpose. Depending on the purpose, events can be put into different categories such as religious events, cultural events, musical events, etc. The following figure lists eight different typologies of events:

Figure 1

Typologies of events

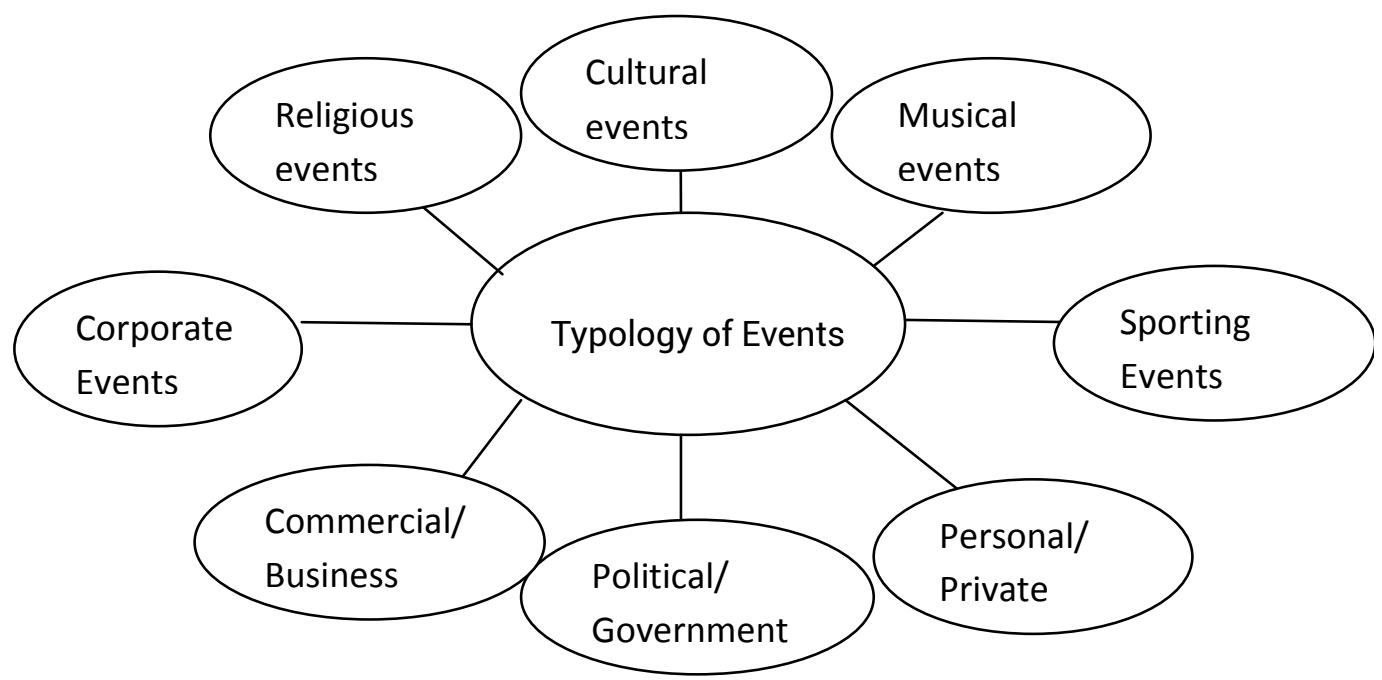

Source: Raj, et.al., 2009 
The organization of every kind of events has certain advantage for the host community or country. Cultural events have social and symbolic values, beliefs, ideologies and traditions of the community. These events are usually celebrated as a form of festivals, in which people gather to celebrate a cause and wish each other on behalf of that auspicious day. It is the time of rejoicing and showing respect to the old age values and traditions that are transferred from generation to generation. Getz and Page (2007) define cultural celebrations as "solemn or joyous events that have cultural meaning" ( $p$. 66). Similarly, Bladen et.al (2012) define cultural events as "those that either present a particular expression of culture or aim to represent the cultural expressions of specific groups" (p. 329). Managing a cultural event is hard work in every respect. Cultural event organizers have to deliver an artistic and cultural program, which appeal to the public. Volunteers are crucial in the delivery of such program that succeeds to enhance the experience of the attendees.

Generally, being a volunteer means contributing with miscellaneous resources to different institutions without being paid in monetary terms. Wilson (2000) defines volunteering as any activity in which time is given freely to benefit another person, group or organization, whereas Stebbins (1996) emphasizes it as a leisure pursuit. There are three key characteristics of the volunteering as pointed out by Cnaan, Handy and Wadsworth: "Volunteering is a specific process with three main characteristics: first, it's a free will; this free will doesn't suppose any monetary rewards; finally, there is always a formal organization, where the volunteering process occurs, where the volunteers help to the beneficiaries, or strangers" (Cnaan et al., 1996, p. 366). Volunteering involves free choice, intended beneficiaries and it is devoid of desire for remuneration.

The growth of events and festival volunteering has broadened the concept of volunteering and has led to the emergence of unconventional forms of volunteering. This development has not only seen a rise in more time-intensive volunteering experiences where the volunteering activity is usually condensed into a few days, but also a greater focus on the personal benefits for volunteers. The volunteering is the largest and the most vital labour force in any cultural event. "Volunteers of community events and festivals often undertaking multi- faceted roles from event leadership through to operations and ensuring that these celebrations are made possible in the absence of big budgets and professional event staff" (Karl, et. al., 2008,p. 73). The volunteers can carry out a wide range of roles from managing the pre-event promotion and welcoming the visitors to acting as event promoters and carrying out production roles.

The success of the event depends on how well the volunteers are managed. The management of the volunteers involves fostering the desire of people to help and get involved while ensuring that it is done in a framework of good practice. Though the volunteer management focuses on the motivation and satisfaction, it requires adopting the practices of human resource management. Cuskelly et al. (2006) suggest that human resource management should include seven discrete functions: planning, recruiting, screening, orientating, training and support, managing performance, and recognizing 
performance. It is important for event managers to implement human resource management practices that enable these functions for paid staff but also for volunteers to some degree (Chelladurai, 2006).

Safrit and Schmiesing (2012) define volunteer management as "the systematic and logical process of working with and through volunteers to achieve and organization's objectives in an ever-changing environment" (p.8). Safrit and Schmiesing affirm the volunteer management model suggested by Kreitner (1998) as effective. Kreitner's model for volunteer management integrates the following seven elements:

1. Planning: making a strategy towards recruiting, engaging and sustaining volunteers; 2. Decision-making: deciding on what volunteers organisation needs, to pick the suitable ones; 3 . Organizing: deciding on who is taking responsibility on being a volunteer coordinator in the organisation, plus dividing job tasks among volunteers, scheduling the volunteers' work; 4. Staffing: recruiting and training volunteers; 5. Communicating: contact between both volunteers, volunteer coordinator and volunteers, employees and volunteers, in terms of technical and other issues; 6 . Motivating: encouraging volunteers to contribute the organisation's goals; 7 . Leading: the volunteer coordinator who acquires leading role-model for volunteers; 8 . Controlling: supervision for volunteers, with applied corrections if necessary. (Safrit and Schmiesing, 2012).

For the effective management of the volunteers in the events, the event management should draft a clear volunteer program, recruit and place the volunteers, orient and train them, supervise and evaluate them. The volunteer plan should be strategically drafted analyzing the needs and expectations of the volunteers. The program should be such that energizes the volunteers and generate their commitment. The volunteer program gives directions for the recruitment, selection, orientation, training, supervision, evaluation as well as retention of the volunteers.

Volunteer management involves the practices of recruiting, enhancing, motivating and leaving volunteers with memorable experience. It is, however, a fact that volunteer management in events differ in some way from the volunteer management in general organizational settings. Kim and Cuskelly (2017) affirm, "Events and festivals deal with a different set of volunteer management challenges because of their temporary or irregular nature, compared to managing long-term volunteers" (p.86).

The study tries to explore the volunteer management in the cultural and community event of Bisket Jatra of Madhyapur Thimi. It interrogates the process of recruitment and tasks division aspect of the volunteer management in the event. By analyzing roles of volunteers, it shows how the community is put in action in the cultural event. It tries to highlight how the ethnic division and sub-divisions uniquely become the basis of the volunteer management in the cultural event.

\section{Methodology}

The qualitative ethnographic research method has been employed in order to 
explore and describe the management process of Bisket Jatra from the view point of volunteers. Primary data are collected by semi structured interviews while secondary data are accessed through scientific articles, books, newspapers and online sources.

Snowball sampling technique was used to choose the interviewees of this research. Using snowball technique ten volunteers were interviewed in order to collect necessary data. Due to the nature of ethnographic data, this research follows the descriptive mode of analysis.

\section{Result and Discussion}

The Bisket is managed by the Pa: Ma or Nayopa: Ma, the sub-castes in the Newar community as they belong to the ancestry of the rulers of Thimi in history. The event inaugurates with their permission. Kasa: or Kayastha hold the responsibility of the logistics management. Similarly, Bhaliduwa are the leaders of storage.

The leaders of the Bisket Jatra create the coordination among the volunteers involved in the event. However, the ways they recruit, screen, orient and train the volunteers differ from the volunteer management practices in general organizational setting since the whole community functions as a team. In other words, volunteers of the Bisket Jatra are the locals and most of them are volunteering as their ancestors had been. They volunteer out of their religious faith, cultural pride and sense of belonging as their volunteering is cross-generational and community-based.

Volunteers in Bisket Jatra of Madhyapur Thimi are delegated to carry the chariots, manage the crowd, polishing the ornaments of the gods and goddesses, cleaning the altars for the resting of the chariots, sacrifice, erecting the pole, making the needle and piercing the tongue, preparing feast, security and managing the crowd, playing Dhimey and ponga and many more. The table 1 shows the activities that precede the main event, the responsible volunteers and the specific sub-casts they belong to.

Table 1

Event Activities and Responsible Volunteers

\section{Customs/Rituals}

Taking out the Ornaments of deities - Tisha:

Pikayegu

Inviting gods and goddesses- Nit kayegu

Offerings collection- Than Bau

Sacrifice of he-buffalo- Mikhu Myay

Setting holy fire in front of houses and temples-Gunsi Chhyekegu

\section{Volunteers Involved}

Kasa: (Kayastha)

Bisankhala:, Kasa:, Pa:ma and Achaju (Karmacharya)

Naaya (Khadgi)

Naaya (Khadgi)

Pa:ma

Journal of Business and Social Sciences (JBSS) 
Instate lord Bhairav idol - Bhaila: Dya: Saligu

Erecting the Pole at Bode - Yo Shin

Splashing holy water throughout the town for making it sacred - Kyo:Ma:La Chinkama: La

Distributing Vermilion - Bhuisinha: La: Lhyegu

Inviting Dhimey Group- Banyedan Biyegu

Playing three-mouthed musical instrument at

Mahalakshmi Temple- Pasta Thayegu

Purifying the idol of Nilbarahi - Lasakus

Making needle for tongue piercing

Preparing feast - Kumvo: Nakegu: Dya

Playing Musical Instruments (Dya: Baja)
Kasa: and Duwa:

Bajracharya

Kumha: (Prajapati)

Pradhans from Layaku

Pradhan

Bhinduwa

Bajracharya

Nakarmi

Bisankhala

Naaya (Khadgi)

In the case of the pre-event rites, as reflected in table 1, the volunteers are well informed about their duties and obligations during volunteering as the roles are determined by their casts and sub-casts and they have been oriented to their respective duties by their ancestors. There is a clear draft of duties and list of responsibilities. Except for the unusual and urgent situations, the volunteers are well-organized and skilled in their duties as instructed by the past generation.

With study of the first day of Bisket, it is found that all the composite Jatras of Bisket are full of colourful events with chariots, parades, Dhimey and other rites. On the eve of the main event, various Jatras take place at different localities. The third or the main day of the Bisket is grand. The main attractions of the event are Sinha: Jatra, spraying of vermilion powder to each other, Swonnikha, the parade of 32 chariots and tongue- piercing event in the locality of Bode. The Swonikha Jatra involves the volunteers of the fixed locality (tole) of Thimi, Bode and Tigani. They carry the chariots and parade through the town in the pre-determined routes, accompanied by hundreds of Dhimey. Table 2 enlists the locality of volunteers and the corresponding chariots they are responsible to carry and parade in the predetermined route.

Table 2

32 Chariots of Swonikha and Locality of Responsible Volunteers

\begin{tabular}{lll}
\hline S.No. & \multicolumn{1}{c}{ Chariots of Deities } & Locality of Assigned Volunteers \\
\hline 1 & Bal Kumari - Kolakhudya: & Balkumari \\
2 & Kalika - Valakhudya: & Balkumari \\
3 & Dakshin Barahi - Kyochhandya: & Dakshin Barahi
\end{tabular}




\begin{tabular}{|c|c|c|}
\hline 4 & Harisiddhi - Hinchodya: & Dakshin Barahi \\
\hline 5 & Ajima - Ajimadhya: & NA \\
\hline 6 & Bishnu Veer - Sunga: Dhya: & Sunga Tole \\
\hline 7 & Pratham Ganesh - Parsikyo Ganedhya: & Parsikyo: Tole \\
\hline 8 & Guru Ganesh- Data: Ganedhya: & Dathu Tole \\
\hline 9 & Asta Vinayak - Bhadaenaya & Bamune \\
\hline 10 & Sthaneshwor Ganesh - Thasma Ganedya: & Balkumari \\
\hline 11 & Tachhu Ganesh - Gatan Ganedya: & Tachhu Tole \\
\hline 12 & Narayan - Natrandya: & Bhulankhel \\
\hline 13 & Siddhi Kali - Inakyodya: & Siddhi Kali \\
\hline 14 & Guru Ganesh - Chode Ganedya: & Chode \\
\hline 15 & Kyosi Ganesh - Kavasina Ganedya: & Bhulankhel \\
\hline 16 & Chapacho Ganesh - Ganedya: & Chapacho \\
\hline 17 & Raj Ganesh - Inayalachhi Ganedya: & Inayalachhi, Nigupukhu \\
\hline 18 & Digu Ganesh & Digu Tole \\
\hline 19 & Gamchanani Ganesh & Gamchanani \\
\hline 20 & Siddhi Ganesh: Shiva: Ganedya & Shiva Tole \\
\hline 21 & Siddhi Ganesh: Narash Ganedya & Nagadesh \\
\hline 22 & Mahalakshmi & Bode \\
\hline 23 & Ta: Dhi: Barahi & Bode \\
\hline 24 & Chidhi Barahi & Bode \\
\hline 25 & Bhorikha Ganesh & Bode \\
\hline 26 & Pacho Ganesh & Bode \\
\hline 27 & Kalika & Bode \\
\hline 28 & Hasimala Ganesh & Bode \\
\hline 29 & Nilbarahi & Tigani \\
\hline 30 & Siddhikali & Lohakilthali \\
\hline 31 & Mohan Vinayak & Layaku \\
\hline 32 & Batuk Bhairab & NA \\
\hline
\end{tabular}


In case of the Swonikha event of Bisket, as shown in table 2, the thirty-two chariots are hold by the volunteers. The volunteers are recruited on the basis of the fixed locality of the community they belong to. It shows motivation of volunteers and the sense of place are directly correlated.

Swonikha is accompanied by Sinha Jatra. The Pa: Ma or Nayopa: Ma spray the vermilion powder on the chariots of the deities and permit to start the event. Then the crowds parade up hurling and smearing vermilion to each other. They sing and dance in the tune of traditional music.

Later, in the day, the crowds swarm to Bode to view the tongue-piercing event. According to the tradition, a person of Shrestha family of Thimi has to pierce his tongue. $\mathrm{He}$ is to observe the ritual of purification and fasting before the event. The Pa: Ma, priest from Mahalakshmi temple, hands over a six-inch long needle made by Nakarmi to a Karmi Naike (local volunteer), who drives it through the tongue of the Shrestha. The tonguepierced man then parades through the area bearing a bamboo rack of oil-lit lamps and has the needle removed on returning the temple. The Karmi Naike removes it and the Nakarmi hammers it into the wall of the temple. Not only the operation and production but also the termination of the event involves various tasks and the designated volunteers take up the charge.

\section{Conclusion}

Volunteers are essential to the successful accomplishment of any cultural and community events. Their committed involvement is integral to the production, operation and staging of the events. It is encouraging to note that Bisket Jatra, cultural event of Madhyapur Thimi, demonstrates a good practice of volunteer management. The volunteer management in the Bisket Jatra also involves the processes of planning for volunteer involvement, recruiting, and selecting, supporting and retaining volunteers. However, it is different to other general practice as the processes, policies and procedures to mobilize and coordinate the volunteers are completely based on the casts and sub-casts and the quarters of Thimi that the volunteers belong to. The volunteers are recruited based on the ancestry and locality they belong to. They are oriented to their designated tasks by their parents or the seniors of the community. The volunteers go on polishing their skills with their experience of the event. The retention of the volunteers is encouraged by the sense of cultural pride and sense of belonging. Such, clear draft of duties and responsibility of volunteers results in the smooth operation of the event and the achievement of the goal. In short, the whole community of Madhyapur Thimi is put through the cultural event of Bisket Jatra in a meaningful way.

\section{References}

Bladen, C., Kennell, J., Abson, E. \& Wilde, N. (2012). Events management: An introduction. London: Routledge.

Chelladurai, P. (2006). Human resource management in sport and recreation ( $2^{\text {nd }}$ ed.). Champaign, IL: Human Kinetics. 
Cnaan, R.A., Handy, F., Wadsworth, M. (1996). Defining who is a volunteer: conceptual and empirical considerations. Nonprofit and Voluntary Sector Quarterly, 25 (3), 364-383. doi: 10.1177/089976409625300.

Cuskelly, G., Hoye, R. \& Auld, C. (2006). Working with volunteers in sport: Theory and practice. London: Routledge.

Getz, D. (2007). Event studies. Oxford: Butterworth-Heinemann.

Getz, D. (2008). Event tourism: Definition, evolution, and research. Tourism Management, 29 (3), 403-428. doi: 10.1016/j.tourman.2007.07.017.

Karl, K. A., Peluchette, J. V., Hall, L. M. (2008). Give them something to smile About: A marketing strategy for recruiting and retaining volunteers. Journal of Nonprofit \& Public Sector Marketing, 20(1), 71-96. doi:10.1080/10495140802165360.

Kim, E. \& Cuskelly, G. (2017). A systematic quantitative review of volunteer management in events. Event Management, 21, 83-100. doi:10.3727/152599517X14809630271195

Prajapati, B. (2017, April 18). Bisket Jatra @ Madhyapur Thimi [Blog post]. Retrieved from https://steemit.com/life/@prajapatibnay/bisket-jatra-madhyapur-thimi/

Razaq, R., Paul, W. and Tashir, R. (2009). Events management: An integrated and practical approach. London: Sage.

Safrit, R.D. \& Schmiesing, R. (2012). Volunteer Models and Management. In: Connors, T.D. (ed.), Volunteer management handbook. Leadership Strategies for Success, $2^{\text {nd }}$ ed., pp. 3-30. New Jersey: Wiley.

Sayami, D. (1972). The Lotus \& the flame: An account on Nepalese Culture. Kathmandu: Department of Information.

Smith, K.A., Baum, T., Holmes, K., Lockstone-Binney, L. (2014). Event volunteering: International perspectives on the event volunteer experience. London: Routledge.

Stebbins, R. A. (1996). Volunteering: A serious leisure perspective. Nonprofit and Voluntary Sector Quarterly, 25(2),211-224.doi: 10.1177/0899764096252005.

Shrestha, S. (2013, April 26). Bisket Jatra: A young perspective. Republica. Retrieved from http:// www.academia.edu.

Volunteering Australia: National survey of volunteering issues (2006). Retrieved from ht t p s: / / w w w. volunteeringaustralia.org/wpcontent/files _ $\mathrm{mf} / 1377045695 \mathrm{VANSVI} 2006$.

Wilson, J. (2000). Volunteering. Annual Review of Sociology, 26, 215-240. doi: abs/10.1146/annurev.soc.26.1.215 